\title{
The Effect Of Somatic, Auditory, Visual, Intelectual and Learning Style Towards Students Knowledge Competency in Junior High School (SMPN 1) Koto Baru Dharmasraya District
}

\author{
Aulia Victorina ${ }^{1 *}$ Ramadhan Sumarmin ${ }^{2}$ \\ ${ }^{1}$ Student of Master Degree Program Biology Department, Math and Natural Science Faculty, Universitas Negeri \\ Padang, Padang, Indonesia \\ ${ }^{2}$ Biology Department, Math and Natural Science Faculty, Universitas Negeri Padang, Padang, Indonesia \\ *Corresponding author. auliavictorina@gmail.com
}

\begin{abstract}
This research is based on students lack of motivation in learning teaching process, learning style, and learning mehod is not quite effective for implementation, teacher-centered learning teaching process, and also students achievement is still low. The purpose of this research is to identify the effect of Somatic, Auditory, Visual, Intelectual towards students' knowledge competency.This kind of research is quazy experimental with Factorial Design 2x3 research design. The population is grade VII students of SMPN 1 Koto Baru 2018/2019. The sample is taking by using Purpose Sampling technique and was decided that VII A as control class when VII B as experimental class. Instrument that is used here is final test question sheet with 25 objective question. The result shows that experimental class get higher score that is 80,87 when control class is 74,87 . It can be concluded that the using of Somatic, Auditory, Visual, Intelectual and learning style can improve students knowledge competency.
\end{abstract}

Keywords: Learning, SAVI Learning model, Learning style, Knowledge competency.

\section{INTRODUCTION}

Education is human needs and it is very important for their peaceful life. Knowledge is related with education and hopefully the higher the education the higher their knowledge will be (Efriani, etc, 2019: 29). According to Degama and Sumarmin (2019:1), education is one of the manifestation of dinamicity and full of culture of human. So that, any developments in education environment is a must and happen as culture changing.

Education in 21 th century can be seen by the development of science and technology in many aspects of people, especially in information and technology. Related what has been stated above, some of the requires aspect that is crucial in education is learning and inovating, mastering media and information and communication and also career life (Aswan, etc., 2018:1) Science is one of the lessons that has important place in education world due to it willl help students in challenging global era.

As one of the aspects in science, IPAis hopefully able to help students to fulfill what is needed in 21th century demand (Arifa, etc, 2019: 20). Also, it hopefully can be a media to to students to learn themselves and also from nature, forward development in implementation in daily life (Sari, etc, 2018: 36), This discussion is related with (Handadi and Sumarmin, 2019: 1) research that is science will help students to find what is needed in this 21 th era.
Government already designing teaching program that fulfill curriculum demand that is determined today; 2013 Curriculum.

Based on Permendikbud No. 22 Year 2016 about education standart process of elemntary level and junior high school level that 2013 curriculum demands that learning teaching process should be integrated with Scientific approach (Eroika etc, 2019:72). On the other hand Sumarmin etc $(2017: 1)$ said that Indonesian government already fixing the education system by purpose and concecutively in every aspects of education, can be seen by application of helding teachers improvement through training and Musyawarah Guru Mata Pelajaran (MGMP) to improve eduaction quality. In this curriculum, teacher needs to involve students to be active in discussion but in reality teachers only implement conventional method like teacher doing speech in front of class.

Study as a process that is conducted by both teachers and student to achieve certain goals (Rahmi etc, 2019: 233). Teachers have important role in classroom because they determine what the students will be. It has the same purpose as in KTSP that demand activities that is connducted by teachers consists of their creativity as facilitator and motivator in forming students competency (Ayu etc, 2018:2). Teachers need to have abiity in choosing strategy or model that is effective in learning teaching process. Related to Anggriawan (2018: 355) said 
that speech method by the teacher is not effective for all learning style because it only suitable for auditory type students. Learning teaching process need to involve students in the process and need to focus not only cognitive aspect but also pshycomotort and affective (Anggraini, etc., 2019: 131).

Method and model that does not involve students in learning teaching process tend to cause misunderstanding. In order to solve this teachers need a strategy that relate topic and phenomenon (Mufit, etc 2018: 3). Related to Sari Etc (2018: 1) research that speech method does not effective because it will speech methoh method is not that effective and will cause students get low achievement.

In learning teaching process rarely that sudents' characteristic is a focus point for teachers. Every students have their own characteristic and different from other. Students level in understanding a lesson is divide by their level.some of them are fast learner when another is slower (Uno, 2008: 108). According to Saldayu, etc, 2019: 1) said that this differentiates is caused by every students have their own speed in understanding the lessson.

The function of knowing learning style of the students is that teachers will find a way to stabilize strategy that teachers use in order to reach learning goal and maximize students potential. Learning style is also one of the factors that determine students achievement.Visual type students is different than auditory which count on their listening skill and kinestetic students like to directly active in learning process (Sari, 2015:16). Teacher should be able to accomodate students' need in learning teaching process so that learning goals will be achieved especially in science lesson (Rijal and Bachtiar, 2015: 16). Learning competency is students reflection of their mastery on 3 aspects; knowledge, attitude and skill (Meliyani etc, 2019: 250). According to (Sarah, etc 2018: 25) Learning process demand that students to built their own knowledge.

Based on interview with science teacher, Ms.Endang Triwarnis Can, S.Pd in SMPN 1 Koto Baru on July 2018, researcher get the data about problems that students face in learning science such as : 1)Low motivation, 2)Heterogeny of learning style, 3)Teaching method is not too effecrive, 4) Teacher centered learning, 5) Low of students achievement

In order to solve those problems, there is Somatic, Auditory, Visual, Intelektual (SAVI)can be used to solve this. Through this model students will be actively involved, senses will also be used. SAVI model will facilitate all of learning style in the classroom. Meier (2002) SAVI is a model that make students actively involved in activities that involves their senses and also ohysically.

Somatic (S) means body movement, Auditory (A) means learning by listening and speaking, Visual (V) means observing and illustrating and Intelectual (I). The implementation of SAVI demands students to be active in experimentation, observating and presentating discussions' result then doing problem solving based on knowledge that they achieved in the classroom. By using SAVI model students will not too dependent on teacher and train them to aspirate their own idea and also improving their motivation on learning teaching process (Sayekti, 2018: 15-16). Also, is also able to combine 3 whole type students; Somatic, Auditory, and visual (Wijayanti, etc., 2013: 3-4).

Some researchers stated that SAVI learning model has good impacts on students. Research that Dewi conducted in 2012 "'The effect of SAVI implementation on Grade X Biological students if SMA N 1 Boyolali 2011/2012', shows that SAVI model has impacts on several aspects of students in cognitive, affective, and psycomotoric. Sihwinedar research (2015) 'Improving biological students achievement by using SAVI (Somatic, Auditory, Visual, and Intelectual on Grade III Elementary Students of SDN Rejoangung 01 2013/2014" stated that SAVI model make students to be more active in learning teaching process and increase their passing grade percentage.

Based on those backrounds, hopefully SAVI model will be able to improve skill competency of students. The researcher has conducted research about it "'The Effect of Somatic, Auditory, Visual, and Intelectual Learning Model Towards competency skill in SMPN 1 Koto Baru Dharmasraya Regency.

\section{MATERIALS AND METHODS}

This kind of research is quantitave in form of quazy experimentalThe design is Factorial design $2 \times 3$. The population is students grade VII SMPN 1 Koto Baru $2018 / 2019$. The sample is taking by using Purposive Sampling technique. VII A as control class and VII B as experimental class. The instrument that is used here is final test that consist of 25 objectives question. Data analizing is by using statistic trial of 2 way Anova.

\section{RESULT AND DISCUSSION}

\subsection{Result}

Table 1. Students' knowledge data

\begin{tabular}{lllll}
\hline \multirow{2}{*}{ Class } & $\begin{array}{l}\text { Learning } \\
\text { Style }\end{array}$ & \multirow{2}{*}{$\mathrm{N}$} & \multicolumn{2}{l}{ Final Test Score } \\
\cline { 3 - 5 } & & $\overline{\boldsymbol{x}}$ & $\mathrm{S}$ \\
\hline \multirow{3}{*}{ Control } & Visual & 16 & 77,00 & 7,44 \\
\cline { 2 - 5 } & Auditory & 7 & 69,14 & 7,90 \\
\cline { 2 - 5 } & Kinesthetic & 7 & 75,42 & 8,46 \\
\cline { 2 - 5 } & All & 30 & 74,80 & 8,18 \\
\hline \multirow{3}{*}{ Experiment } & Visual & 21 & 82,00 & 6,98 \\
\cline { 2 - 5 } & Auditory & 5 & 77,60 & 3,84 \\
\cline { 2 - 5 } & Kinesthetic & 4 & 79,00 & 4,76 \\
\cline { 2 - 5 } Exp:N & : Total Partisipant & 30 & 80.87 & 6,42 \\
$\overline{\boldsymbol{x}}$ & : Average & & \\
$\mathrm{S}$ & $:$ Standart deviation & & & \\
& & &
\end{tabular}


The result shows that $S A V I$ is effective in improving students competency. It can bee seen by the achievement that conventional students achieve by using SAVI. The use of $S A V I$ enable students to find knowledge by themselves. Learning teaching process involves all senses different than conventional that is teacher centered. Students built Students can built knowledge from their experience that enable them to comprehend the lesson in which with their sense actively used that be name as active learning (Rochintaniawati, 2014).

According to Nisa (Nisa, 2017: 50) Learning by doing is the right way to get deep comprehention. By using $S A V I$ model students will learn the application of of knowledge in daily life. In SAVI, students will be train to solve problems and doing critical thinking to certain phenomenon. It related to Ghaida,

Nisa etc 2017, learning model SAVI is effective for science. As one of the science aspects, science hopefully fulfill students need to face 21 th century. (Arifa, etc, 2019: 20).

One of the factors that affects students achievement in knowledge aspect is sintax from SAVI model as it is related in RPP.It is important to fulfill all of the aspects in order to maintain and developing effective and efficient learning so that the goals will be achieved. According to (Siswoyuono dan susilo, 2016) SAVI focus on critical thinking and physical activity from students so it will improve their comprehention about the lesson.

\section{CONCLUSION}

Based on research above it can be concluded that the effect of using learning model SAVI can improve students knowledge competency.

\section{REFERENCES}

[1] Anggraini, N., Sumarmin, R., Ardi, A., \& Yuniarti, E. (2019). Application of Guided Inquiry Learning Model to Cognitive Competencies of Students Assisted by Mind Map in Senior High School UNP Laboratory Development. Atrium Pendidikan Biologi, 4(2), 131-138.

[2] Anggriawan, V., Razak, A., \& Sumarmin, R. (2018). Influence of Guided Inquiry Based on Learning Styles for Student Outcomes (Cognitive) Grade XI in Senior High School 3 Kerinci. International Journal of Progressive Sciences and Technologies (IJPSAT), 6(2), 1.

[3] Arifa, S., Ardi, A., Yogica, R., \& Sumarmin, R. (2019). The Effect of Make A Match Learning Model on Students' Science Cognitive Competency of Junior High School Students In Payakumbuh City. Atrium Pendidikan Biologi, 4(2), 20-28.
This research is also identify learning style of both class. It is conducted by giving questionnaire to participants. The different learning style of both group will affect their achievement.Visual type students is different than auditory which count on their listening skill and kinestetic students like to directly active in learning process (Sari, 2014:3)

Based on observation that has been conducted it shows that Two way Anovashows average scoreof experimental class is higher than control one. Learning competency of students knowledge wether it Auditory, Visual or Kinesthetic getting improved by $S A V I$ model that follows coventional class. In both class it is identified that visual style is dominated in learning style. Students with visual type will learn by watching, Auditory type will learn by listening and kinesthetic one will learn through activity. All students have all the style but only one will be dominated (Bire, etc., 2014: 169).

On conventional learning students only focus on using one sense only. They only listen what their teacher said. So only listening sense is used here. On the other hand every students have heterogenous way of learning wether it is by visual, listening or by physical activity. Those are style that students get used to and teacher need to use technique that affect all of that style so SAVI is the answer of that problem.

[4] Aswan, D. M., Lufri, L., \& Sumarmin, R. (2018, April). Influence of Problem Based Learning on Critical Thinking Skills and Competence Class VIII SMPN 1 Gunuang Omeh, 2016/2017. In IOP Conference Series: Materials Science and Engineering (Vol. 335, No. 1, p. 012128). IOP Publishing.

[5] Ayu, D. M., Sumarmin, R., \& Lufri, L. (2018). The Development of Biology Modul With LKS Orientation Problem Based Learning (PBL) In Topic Environmental Pollution For Grade X. Bioeducation Journal, 2(1), 76-86.

[6] Bire, A. L., Geradus, U., \& Bire, J. (2014). Pengaruh gaya belajar visual, Auditoryal, dan Kinesthetic terhadap prestasi belajar siswa. Jurnal Kependidikan: Penelitian Inovasi Pembelajaran, 44(2).

[7] Degama, I. K., \& Sumarmin, R. (2019). Influence of Problem Based Learning Model and EntryBehaviours on Student Biological Competency of Class X, Senior High School 4 Sungai Penuh. International Journal of Progressive Sciences and Technologies (IJPSAT), 13(2): 1

[8] Dewi, W. M. M., \& Santosa, S. (2012). Pengaruh Penerapan SAVI terhadap Hasil Belajar Biologi Siswa Kelas X SMA N I Boyolali Tahun Pelajaran 2011/2012. In Proceeding Biology Education Conference: Biology, Science, 
Enviromental, and Learning (Vol. 9, No. 1).

[9] Efriani, N., Zulyusri, Z., Rahmi, Y. L., \& Sumarmin, R. (2019). Identification Of Students Of Misconception Junior High School Class VII Sutera On The Topic Photosintesis Using Two Tier Diagnostic Test. Atrium Pendidikan Biologi, 4(2), 29-36.

[10] Eroika, V., Sumarmin, R., Helendra, H., \& Yuniarti, E. (2019). The Needs Analysis of The Develop of Biology Module Based On Scientific Approach for Senior High School Grade XI Students. Atrium Pendidikan Biologi, 4(2), 7281.

[11] Handadi, R., \& Sumarmin, R. (2019). Influence of Role Playing Model and Entry Behaviour to Biology Competence of Class VIII Student of SMP Negeri 17 Kerinci. International Journal of Progressive Sciences and Technologies (IJPSAT), 14(2): 1.

[12]Meier, D. (2002). The Accelerated Learning Handbook. Bandung: Kaifa.

[13] Meliyani, M., Darussyamsu, R., Yogica, R., \& Sumarmin, R. (2019). The Relationship Between Learning Styles and Biology Cognitive Competency of Senior High School Students. Atrium Pendidikan Biologi, 4(1), 249-255.

[14] Mufit, F., Festiyed, F., Fauzan, A., \& Lufri, L. (2018, April). Impact of Learning Model Based on Cognitive Conflict toward Student's Conceptual Understanding. In IOP Conference Series: Materials Science and Engineering (Vol. 335, No. 1, p. 012072). IOP Publishing.

[15] Nisa, G., Ansori, I., \& Hartati, S. (2017). Keefektifan Model Somatic, Auditory, Intellectually, Visualization Pada Mata Pelajaran Ipa. Jurnal Kreatif: Jurnal Kependidikan Dasar, $7(1)$.

[16] Rahmi, N. A., Fitri, R., Selaras, G. H., \& Sumarmin, R. (2019). Analysis Correlation between Learning Motivation and Learning Outcomes of Junior High School Students In Padang. Atrium Pendidikan Biologi, 4(1), 232238.

[17] Rijal, S., \& Bachtiar, S. (2015). Hubungan antara Sikap, Kemandirian Belajar, dan Gaya Belajar dengan Hasil Belajar Kognitif Siswa. Jurnal Bioedukatika, 3(2), 15-20.

[18] Rochintaniawati, D. 2014. Pembelajaran IPA dengan menggunakan Pendekatan Saintifik dalam Kurikulum 2013. Jurnal Prosiding Seminar Nasional Pendidikan MIPA 2014 ISBN 978-602-19877-2-8.

[19] Saldayu, F., Ristiono, R., Yogica, R., \& Sumarmin, R. (2019). Relationship of Multiple Intelligence with Cognitive Learning Outcomes of Students in Class VIII Science Subjects of SMP 13 Padang. Atrium Pendidikan Biologi,
4(1), 1-7.

[20] Sarah, S., Lufri, L., dan Sumarmin, R. (2018). Pengaruh Model Pembelajaran Problem Solving terhadap Kompetensi Belajar IPA Peserta Didik Kelas VIII SMP Negeri 13 Padang. Jurnal Eksakta Pendidikan (JEP), 2(1), 25-32.

[21] Sari, A. K. (2014). Analisis Karakteristik Gaya Belajar VAK (Visual, Auditoryal, Kinesthetic) Mahasiswa Pendidikan Informatika Angkatan 2014. Edutic-Scientific Journal of Informatics Education, 1(1).

[22] Sari, Y. R., Ahda, Y., \& Sumarmin, R. (2018). Development of Teaching Problem Learning Model and Ability to Sharing Ability to Biological Competence Class VII Students of MTsN Pakan Rabaa. BIODIK, 4(1), 36-47.

[23] Sayekti, W. (2018). Pengaruh Model Pembelajaran Somatic, Auditory, Visual, Intelektual (Savi) Terhadap Hasil Belajar Matematika Siswa Kelas V Min 9 Bandar Lampung. (SKRIPSI). Lampung: Universitas Islam Negeri (Uin) Raden Intan Lampung. (Dipubikasikan).

[24] Sihwinedar, R. (2015). Meningkatkan Hasil Belajar Ipa Melalui Penerapan Model Pembelajaran Savi (Somatis, Auditory, Visual, Dan Intelektual) Pada Siswa Kelas Iii Sdn Rejoagung 01 Semboro Tahun Pelajaran 2013/2014. Pancaran Pendidikan, 4(4), 137-148.

[25] Siswoyuono, A. M., \& Susilo, B. E. (2016). Komparasi pembelajaran SAVI dan REACT pada kemampuan pemecahan masalah siswa kelas-VIII materi kubus dan balok. Beta: Jurnal Tadris Matematika, 9(1), 15-33.

[26] Sumarmin, R., Pardismi, P., \& Gusril, G. (2017). The Implementation of Cooperative Learning Type Numbered Heads Together to Improved Students Learning Competence of BiologyClass $\mathrm{X}$ MIA 2 SMA Negeri 2 Solok Selatan. Bioeducation Journal, 1(2), 36- 49.

[27] Wijayanti, T. F, B. A. Prayitmo, Marjono. (2013). "Pengaruh Pendekatan SAVI Melalui Model Pembelajaran Kooperatif Tipe Stad Terhadap Hasil Belajar Pada Siswa Kelas VII SMP Negeri 14 Surakarta”. Jurnal Pendidikan Biologi,5(1), 3-4. 